\title{
Effect of Biofertilizers and Micronutrients on Nutrient Uptake, Growth, Yield and Yield Attributes of Lentil (Lens culinaris L.)
}

\author{
Amit Kumar Tiwari*, Ved Prakash, Atik Ahmad and R.P. Singh \\ Department of Soil Science and Agriculture Chemistry, Narendra Deva University of \\ Agriculture and Technology, Narendra Nagar, Faizabad, U.P., India \\ *Corresponding author
}

\begin{tabular}{|l|}
\hline K e y w o r d s \\
Rhizobium, PSB, \\
$\begin{array}{l}\text { Ammonium } \\
\text { molybdate and Zinc } \\
\text { sulphate }\end{array}$ \\
\hline Article Info \\
\hline $\begin{array}{l}\text { Accepted: } \\
\text { 26 January 2018 } \\
\text { Available Online: } \\
\text { 10 February } 2018\end{array}$ \\
\hline
\end{tabular}

\section{A B S T R A C T}

A field experiment was conducted to study the effect of biofertilizers (Rhizobium and PSB) and micronutrients ( $\mathrm{Zn}$ and $\mathrm{Mo}$ ) on nutrient uptake, growth, yield and yield attributing characters of lentil. The experiment was laid out in randomized block design with the eight treatments viz. $\mathrm{T}_{1}$ (control), $\mathrm{T}_{2}$ (Seed inoculation with Rhizobium $\left.+\mathrm{PSB}\right), \mathrm{T}_{3}($ Seed inoculation with Rhizobium $+\mathrm{PSB}+1 \mathrm{~g}$ Ammonium Molybdate/ kg seed), $\mathrm{T}_{4}$ (RDF, 20:60:20 kg N, $\mathrm{P}_{2} \mathrm{O}_{5}$ and $\left.\mathrm{K}_{2} \mathrm{O}\right), \mathrm{T}_{5}\left(\mathrm{RDF}+\right.$ Seed Inoculation with Rhizobium + PSB), $\mathrm{T}_{6}$ (RDF+ Seed Inoculation with Rhizobium + PSB+1 g Ammonium Molybdate/ kg seed), $\mathrm{T}_{7}$ $(\mathrm{RDF}+25 \mathrm{~kg} \mathrm{ZnSO} / \mathrm{ha})$ and $\mathrm{T}_{8}(\mathrm{RDF}+25 \mathrm{~kg} \mathrm{ZnSO} /$ ha + Seed inoculation with Rhizobium + PSB + 1.0g Ammonium Molybdate/ kg seed)and three replications with lentil variety NDL-1.The soil of experimental field was silt loam in texture, pH: 8.45, EC: 0.34 $\mathrm{dSm}^{-1}$, O.C: $0.31 \%$, Available $\mathrm{N} 137 \mathrm{~kg} \mathrm{ha}^{-1}$, available P $12 \mathrm{~kg} \mathrm{ha}^{-1}$, available $\mathrm{K} 211 \mathrm{~kg} \mathrm{ha}^{-}$ ${ }^{1}$ and bacterial population $(33.0 \mathrm{cfu})$. The highest uptake of $\mathrm{N}\left(91.55 \mathrm{~kg} \mathrm{ha}^{-1}\right), \mathrm{P}(8.57 \mathrm{~kg}$ $\left.\mathrm{ha}^{-1}\right), \mathrm{Zn}$ (654.66 $\left.\mathrm{g} \mathrm{ha}^{-1}\right)$ and Mo (278.69 $\mathrm{g}$ ha-1) by lentil crop was found with the treatments $\mathrm{T}_{8}$, followed by $\mathrm{T}_{6}$. The maximum growth, yield and yield attributing characters were recorded in T8, which was statistically at par with T6 and significantly superior with rest of the treatments. Whereas maximum 1000 seed weight (26.00) also was recorded in the treatment $\mathrm{T}_{8}$, which was statistically at par with rest of the treatments. The minimum 1000 seed weight was recorded in control.

\section{Introduction}

Lentil (Lens culinaris L.) is an important Rabi pulse crop extensively grown in India. The yield level of lentil is generally low because it is less cared crop and mostly grown in poor soil without manures and fertilizers. Regular depletion of nutrient resources of soil has led to emergence of several nutrient deficiencies in many crops including lentil. This is because the greater is the production, the higher and faster are the rate of nutrients exhation from the soil. As a leguminous crop, it utilizes atmospheric nitrogen to meet its partial nitrogen requirement and thus occupies an important place in crop rotation in different part of the country. It is the most suitable crop for rainfed conditions, because of its deep root system and capability to stand in drought condition. In comparison to any other rabi crops of similar condition, except gram, it is greatly esteemed for its ability to give 
satisfactory yield even under sub-optimum condition and in year of low winter rainfall.

Lentil seeds contain about 11.20 percent water, 25.0 percent protein, 1.0 percent fat, 55.8 percent carbohydrate, 3.7 percent fiber and 3.3 percent ash. The role of lentil as a legume crop in building up soil fertility is well known.

Biofertilizers are gaining importance as they are ecofriendly, non-hazardous and non-toxic. A substantial number of bacterial species, mostly those associated with the plant rhizosphere, may exert a beneficial effect upon plant growth. Biofertilizers include mainly the nitrogen fixing, phosphate solubilizing and plant growth promoting micro-organism. Inoculating pulse crops with rhizobia to add nitrogen is routine for most growers. The presence of efficient and specific strains of Rhizobium in the rhizosphere is one of the most important requirements for proper establishment and growth of grain legume plant. Phosphate solubilizing bacteria partly solubilizes inorganic and insoluble phosphate and improves applied phosphorus use efficiency stimulating plant growth by providing hormone, vitamin and other growth promoting substances (Gyaneshwar et al., 2002).

The function of most micronutrients in plants and soils for the most part is widely misunderstood. One example of this is zinc and its relative importance in plants' growth. Zinc plays a vital role in the synthesis of protein and nucleic acid and help in the utilization of nitrogen and phosphorus in plant. It also promotes nodulation and nitrogen fixation of leguminous crops.

Molybdenum is a trace element found in the soil and is required for growth of most biological organisms including plants and animals. Molybdenum plays a vital role in nitrogen fixation through its effect on nitrogenase enzyme of nodule in leguminous plants. The chief role of molybdenum is to activate nitrate reductase enzyme during nitrogen metabolism (Possinghum, 1956, 57).

\section{Materials and Methods}

The experiment was conducted during Rabi season of 2015-16 at G.P.B. Farm of the Narendra Deva University of Agriculture and technology, Kumarganj, Faizabad U.P. The experiment was laid out in a Randomized Block Design with eight treatment combination viz. $\mathrm{T}_{1}$ (control), $\mathrm{T}_{2}$ (Seed inoculation with Rhizobium $+\mathrm{PSB}), \mathrm{T}_{3}$ (Seed inoculation with Rhizobium $+\mathrm{PSB}+1 \mathrm{~g}$ Ammonium Molybdate/ $\mathrm{kg}$ seed), $\mathrm{T}_{4}$ ((RDF, 20:60:20 kg N, $\mathrm{P}_{2} \mathrm{O}_{5}$ and $\left.\mathrm{K}_{2} \mathrm{O}\right), \mathrm{T}_{5}(\mathrm{RDF}+$ Seed Inoculation with Rhizobium + PSB), $\mathrm{T}_{6}$ (RDF+ Seed Inoculation with Rhizobium + $\mathrm{PSB}+1 \mathrm{~g}$ Ammonium Molybdate/ $\mathrm{kg}$ seed), $\mathrm{T}_{7}$ $\left(\mathrm{RDF}+25 \mathrm{~kg} \mathrm{ZnSO}_{4} / \mathrm{ha}\right)$ and $\mathrm{T}_{8}(\mathrm{RDF}+25 \mathrm{~kg}$ $\mathrm{ZnSO}_{4} /$ ha + Seed inoculation with Rhizobium + PSB + 1.0g Ammonium Molybdate/ kg seed) with three replications. The soil of experimental field was silt loam in texture, pH: 8.45, EC: $0.34 \mathrm{dSm}^{-1}$, O.C: $0.31 \%$, Available N $137 \mathrm{~kg} \mathrm{ha}^{-1}$, available P $12 \mathrm{~kg} \mathrm{ha}^{-}$ ${ }^{1}$, available $\mathrm{K} 211 \mathrm{~kg} \mathrm{a}^{-}$. The sources of $\mathrm{N}, \mathrm{P}$, $\mathrm{K}$, $\mathrm{Zn}$ and Mo were urea, single superphosphate, muriate of potash ammonium molybdate andzinc sulphate respectively. The seeds were sown on $29^{\text {th }}$ November 2015 with seed rate of $40 \mathrm{~kg} / \mathrm{ha}$ and at a distance of 25 $\mathrm{cm}$ line to line. Crop management practices were done as perschedule and necessity.

After complete emergence of seed, plant to plant spacing of $10 \mathrm{~cm}$ was maintained. There after plant population per square meter was counted. The plant height was measured from the ground level to top position of plant in $\mathrm{cm}$ with the help of meter scale based on five randomly selected plants and averaged out for each plant. The observation on plant height 
was recorded at harvest stages of crop. For counting number of nodules per plant, five plants were selected and up rooted with the help of khurpi and washed without any damage to the root. The number of nodules per plant was counted at 60 DAS. Nodules were carefully detached from the roots of 5 selected plants from each replication and pooled together. The number of nodules per plant was calculated by dividing the total number of nodules with the number of plants. The fresh weight of nodules of five selected plants was recorded at 60 days stage, and their average was calculated. After recording the fresh weight, the nodules were oven dried at $60^{\circ} \mathrm{C}$ for 8 hours to a constant weight and dry weight of nodules were recorded. Nitrogen, phosphorus and molybdenum content in seed and stover was determined by micro kjeldahl, vanadomolybdo phosphoric yellow colour, using water and ammonium oxalate extractant method, respectively (Jackson, 1973). The zinc content in the plant was estimated by atomic absorption spectrophotometer using DTPA extractant (Shaw and Dean, 1952). Nutrient uptake (seed and stover) was calculated with the help of following formulae:-

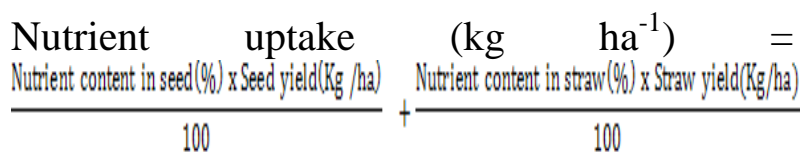

The recovery of seeds from the total dry matter is considered as harvest index, which is expressed in percentage. It was calculated by the following formulae.

Harvest index $(\%)=($ Seed yield $/$ Biological yield) x 100

The total number of pods in 5 randomly selected plants were counted and averaged to get number of pods per pant. The number of pods in randomly selected five plants from each replication was counted for seeds and number of grains per pod was calculated. From each treatment 1000 seed were counted and weighed to express the weight in gram.

\section{Results and Discussion}

\section{Growth}

Data present in table 1 reveal that seed inoculation with rhizobium, PSB, ammonium molybdate and application of RDF along with zinc sulphate, recorded significant increase all growth parameters (plant height, number of nodules at $60 \mathrm{DAS}$, fresh and dry weight of nodules at 60 DAS).

It clearly indicates that the treatments had no effect on plant population and statistically they were at par. Maximum plant height $(58.24 \mathrm{~cm})$ was recorded with the treatment $\mathrm{T}_{8}$ which was statistically at par with the treatment $\mathrm{T}_{6}$ and significantly superior over rest of treatments. The plant height was significantly influenced by various treatments.

The application of biofertilizers, micronutrients and RDF enhanced the plant height appreciably at harvest stages. The maximum plant height was recorded in the $\mathrm{T}_{8}$ $(\mathrm{RDF}+25 \mathrm{~kg} \mathrm{ZnSO} 4 /$ ha + Seed inoculation with Rhizobium + PSB $+1.0 \mathrm{~g}$ Ammonium Molybdate/ kg seed). Increase in plant height might be attributed to the fact that the better nourishment causes beneficial effects such as accelerated rate of photosynthesis, assimilation, cell division and vegetative growth. These results are in agreement with the findings of Singh et al., (2007).

The highest number of nodules (8.80), fresh $(25.26 \mathrm{mg})$ and dry $(5.05 \mathrm{mg})$ weight of nodules plant ${ }^{-1}$ was recorded with the treatment $\mathrm{T}_{8}$, which statistically at par with the treatment $\mathrm{T}_{6}$ and significantly superior over rest of the treatments. The highest weight of nodules plant $^{-1}$ was also recorded with the treatment 
$\mathrm{T}_{8}$. It might be due to the enhanced and established good root system by the seed treatment with rhizobium, ammonium molybdate and application of $\mathrm{ZnSO}_{4}$. Favourable responses of Rhizobium, $\mathrm{Zn}$ and Mo have also been reported by Johal and Chahal, 1994 and Kumpawat and Manohar, 1994.

\section{Yield}

The data (Table 1) on yield and yield attributes of lentil clearly show that all the parameters significantly higher in all the treatments over control.

It was observed that the maximum grain (1457 $\mathrm{kg} \mathrm{ha}^{-1}$ ) yield was recorded with the treatment $\mathrm{T}_{8}\left(\mathrm{RDF}+25 \mathrm{~kg} \mathrm{ZnSO}{ }_{4} /\right.$ ha + Seed inoculation with Rhizobium + PSB + 1.0g Ammonium Molybdate/ $\mathrm{kg}$ seed) which was statistically at par with treatment $\mathrm{T}_{6}$ (RDF+ Seed Inoculation with Rhizobium + PSB+1 g Ammonium Molybdate/ $\mathrm{kg}$ seed) and significantly superior overrest of the treatments.

The minimum grain $\left(860 \mathrm{~kg} \mathrm{ha}^{-1}\right)$ yield was obtain in the control. Similarly, maximum straw yield $\left(2365 \mathrm{~kg} \mathrm{ha}^{-1}\right)$ was recorded with the treatment $\mathrm{T}_{8}$, which was statistically at par with the treatments $\mathrm{T}_{6}$ and significantly superior over the rest of the treatments.

The grain and straw yield of lentil were significantly influenced by various treatments. The maximum increment in grain as well as straw yield were observed with the treatment $\mathrm{T}_{8}$ (RDF + $25 \mathrm{~kg} \mathrm{ZnSO} \mathrm{Zn}_{4} /$ ha +Seed inoculation with Rhizobium + PSB + 1.0g Ammonium Molybdate/ $\mathrm{kg}$ seed) followed by $\mathrm{T}_{6}$ (RDF+Seed inoculation with Rhizobium + PSB + 1.0g Ammonium Molybdate/ kg seed). Grain and straw yield under various treatments $\left(\mathrm{T}_{8}, \mathrm{~T}_{7}, \mathrm{~T}_{6}, \mathrm{~T}_{5}, \mathrm{~T}_{4}\right.$ and $\mathrm{T}_{3}$ ) gave better results over control. The increase in grain and straw yield of lentil might be due to improvement in the efficiency and utilization of native as well as applied nutrients. These results also corroborate with the findings of Kumar et al., (1993), Hafeez et al., (2000) and Shah et al., (2000).

\section{Yield attributes}

The data (Table 1) on yield attributing characters of lentil as affected by different treatments clearly show the significant difference for number of pods plant ${ }^{-1}$ and number of seeds pod $^{-1}$ in lentil.

The maximum number of pods (116.40) per plant were recorded with the treatment $\mathrm{T}_{8}$ $\left(\mathrm{RDF}+25 \mathrm{~kg} \mathrm{ZnSO}_{4} /\right.$ ha + Seed inoculation with Rhizobium + PSB + 1.0g Ammonium Molybdate/ $\mathrm{kg}$ seed), which was statistically at par with the treatment $\mathrm{T}_{6} \quad(\mathrm{RDF}+\mathrm{Seed}$ inoculation with Rhizobium + PSB + 1.0g Ammonium Molybdate/ $\mathrm{kg}$ seed), having 106.40 pods plant ${ }^{-1}$ and significantly superior over rest of the treatments.

The minimum number of pods per plant was recorded under control. Similar trend was also recorded with respect to no. of seeds pod ${ }^{-1}$.

Minimum number of seeds (1.20) per pod recorded under the control.

The maximum test weight $(26.00 \mathrm{~g})$ was reccorded in treatment $\mathrm{T}_{8}$ which was statistically at par with rest of the treatments. The minimum 1000 seed weight was recorded in control.

The increase in yield attributes might be mainly due to increase in photosynthesis activity of leaves, translocation of photosynthates from source to sink and nutrient's uptake. These results corroborate with the finding of Mishra and Tiwari (2001) and Hossain et al., (2010). 
Table.1 Effect of biofertilizers and micronutrients on yield attributes and yield of lentil crop

\begin{tabular}{|c|c|c|c|c|c|c|c|c|c|c|}
\hline \multirow[t]{2}{*}{$\begin{array}{l}\text { Si. } \\
\text { No. }\end{array}$} & \multirow{2}{*}{$\begin{array}{l}\text { Initial } \\
\text { plant } \\
\text { populat } \\
\text { ionm }^{-2}\end{array}$} & \multirow{2}{*}{$\begin{array}{c}\text { Plant } \\
\text { height } \\
(\mathrm{cm})\end{array}$} & \multirow{2}{*}{$\begin{array}{c}\text { No. of } \\
\text { nodules } \\
\text { at } 60 \\
\text { DAS }\end{array}$} & \multicolumn{2}{|c|}{$\begin{array}{l}\text { Weight of nodules } \\
\text { at } 60 \text { DAS(mg) }\end{array}$} & \multirow{2}{*}{$\begin{array}{l}\text { No. of } \\
\text { pods } \\
\text { plant }^{-1}\end{array}$} & \multirow{2}{*}{$\begin{array}{l}\text { No. of } \\
\text { seeds } \\
\text { pod }^{-1}\end{array}$} & \multirow{2}{*}{$\begin{array}{l}1000 \\
\text { seed } \\
\text { weight } \\
\text { (g) }\end{array}$} & \multicolumn{2}{|c|}{ Yield (kg ha') } \\
\hline & & & & & & & & & Grain & Straw \\
\hline$T_{1}$ & 84.33 & 49.36 & 16.40 & 19.32 & 3.87 & 96.60 & 1.20 & 24.00 & 860 & 1657 \\
\hline$T_{2}$ & 84.67 & 50.54 & 19.00 & 20.81 & 4.16 & 98.60 & 1.40 & 24.30 & 926 & 1725 \\
\hline $\mathbf{T}_{3}$ & 84.67 & 51.07 & 20.00 & 22.09 & 4.42 & 100.40 & 1.40 & 27.70 & 988 & 1789 \\
\hline $\mathrm{T}_{4}$ & 85.00 & 51.37 & 18.60 & 20.29 & 4.06 & 102.00 & 1.40 & 24.80 & 1168 & 2068 \\
\hline $\mathbf{T}_{5}$ & 85.33 & 51.74 & 22.60 & 23.71 & 4.54 & 104.40 & 1.60 & 25.20 & 1226 & 2125 \\
\hline $\mathrm{T}_{6}$ & 85.67 & 53.56 & 24.60 & 23.90 & 4.78 & 108.60 & 1.80 & 25.70 & 1330 & 2236 \\
\hline $\mathbf{T}_{7}$ & 85.00 & 52.04 & 21.60 & 22.29 & 4.46 & 106.40 & 1.60 & 25.50 & 1275 & 2175 \\
\hline $\mathrm{T}_{8}$ & 85.67 & 58.24 & 25.20 & 25.26 & 5.05 & 116.40 & 1.80 & 26.00 & 1457 & 2365 \\
\hline SEm \pm & 0.50 & 1.57 & 1.26 & 0.26 & 0.13 & 3.21 & 0.05 & 0.73 & 44.33 & 59.28 \\
\hline $\begin{array}{l}\text { C.D. } \\
(P=0.05\end{array}$ & NS & 4.76 & 3.81 & 0.79 & 0.40 & 9.75 & 0.14 & NS & 134.47 & 179.79 \\
\hline
\end{tabular}

Table.2 Effect of biofertilizers and micronutrients on content and uptake of Nutrients by lentil crop

\begin{tabular}{|c|c|c|c|c|c|c|c|c|}
\hline \multirow{3}{*}{$\begin{array}{l}\text { Si. } \\
\text { No. }\end{array}$} & \multicolumn{4}{|c|}{ Total nutrient content } & \multicolumn{4}{|c|}{ Total nutrient uptake } \\
\hline & \multicolumn{2}{|c|}{$\left(\mathrm{kg} / \mathrm{ha}^{-1}\right)$} & \multicolumn{2}{|c|}{ ppm } & \multicolumn{2}{|c|}{$\mathrm{Kg} \mathrm{ha}^{-1}$} & \multicolumn{2}{|c|}{$\mathrm{g} \mathrm{ha}^{-1}$} \\
\hline & $\mathbf{N}$ & $\mathbf{P}$ & $\mathbf{Z n}$ & Mo & $\mathbf{N}$ & $\mathbf{P}$ & $\mathbf{Z n}$ & Mo \\
\hline T1 & 5.04 & 0.36 & 40.65 & 16.24 & 54.81 & 3.87 & 406.63 & 171.10 \\
\hline T2 & 5.12 & 0.38 & 40.65 & 16.25 & 59.30 & 4.40 & 435.62 & 182.32 \\
\hline T3 & 5.13 & 0.40 & 40.71 & 16.28 & 62.57 & 4.85 & 460.98 & 193.66 \\
\hline T4 & 5.15 & 0.41 & 40.74 & 16.29 & 74.83 & 5.97 & 541.84 & 225.37 \\
\hline T5 & 5.16 & 0.43 & 40.78 & 16.40 & 76.67 & 6.43 & 565.94 & 234.29 \\
\hline T6 & 5.27 & 0.47 & 41.04 & 16.67 & 83.76 & 7.63 & 612.62 & 257.83 \\
\hline $\mathrm{T7}$ & 5.21 & 0.45 & 40.82 & 16.62 & 79.98 & 6.93 & 586.76 & 244.01 \\
\hline $\mathrm{T} 8$ & 5.35 & 0.49 & 41.48 & 16.74 & 91.55 & 8.57 & 654.66 & 278.69 \\
\hline SEm \pm & 0.15 & 0.01 & 0.64 & 0.47 & 2.23 & 0.28 & 20.05 & 7.01 \\
\hline $\begin{array}{l}\text { C.D. } \\
(P=0.05)\end{array}$ & 0.46 & 0.03 & 1.94 & 1.44 & 6.76 & 0.86 & 60.81 & 20.93 \\
\hline
\end{tabular}

\section{Nutrient content and uptake}

The data presented in Table 2 revealed that, the values of total nitrogen, phosphorus, zinc and molybdenum respectively content attain the level of significance with the mean of $5.35 \%$ respectively. However highest total $\mathrm{N}$, $\mathrm{P}, \mathrm{Zn}$ and Mo content were recorded in treatment $\mathrm{T}_{8}$, this treatment was statistically at par with $\mathrm{T}_{6}$ and significantly superior with rest of other treatments. The minimum total nitrogen content was recorded in control treatment. Treatment RDF $+25 \mathrm{~kg} \mathrm{ZnSO}_{4} /$ ha + Seed inoculation with Rhizobium + PSB + $1.0 \mathrm{~g}$ Ammonium Molybdate/ $\mathrm{kg}$ seed recorded significant total $\mathrm{N}, \mathrm{P}, \mathrm{Zn}$ and $\mathrm{Mo}$ content over control treatment and was found at par with $\mathrm{RDF}+$ Seed inoculation with Rhizobium + PSB $+1.0 \mathrm{~g}$ Ammonium Molybdate/ kg seed.

The data on uptake of nutrients (N, P, Zn and Mo) by lentil crop as influenced by various treatments have been presented in Table 2. It 
clearly indicates that the maximum uptake of $\mathrm{N}, \mathrm{P}, \mathrm{Zn}$ and Mo (91.55 $\left.\mathrm{kg} \mathrm{ha}^{-1}\right)$ was recorded with the treatment $\mathrm{T}_{8}\left(\mathrm{RDF}+25 \mathrm{~kg} \mathrm{ZnSO}_{4} /\right.$ ha + Seed inoculation with Rhizobium + PSB $+1.0 \mathrm{~g}$ Ammonium Molybdate/ kg seed) which was significantly superior over rest of the treatments. The nitrogen uptake increased with the application of fertilizers with or without biofertilizers. It might be due to favorable soil conditions which enhanced nutrient availability and nutrient uptake as well as a better growth and activity of roots. Similar findings were observed byIdris and Snadhu (1979), Jagdale et al., (1980), Bera et al., (2013).

The data in respect of phosphorus uptake by lentil present in the Table 2. The maximum phosphorusuptake $\left(8.57 \mathrm{~kg} \mathrm{ha}^{-1}\right)$ was recorded with the treatment $\mathrm{T}_{8}\left(\mathrm{RDF}+25 \mathrm{~kg} \mathrm{ZnSO}_{4} /\right.$ ha + Seed inoculation with Rhizobium + PSB $+1.0 \mathrm{~g}$ Ammonium Molybdate/ $\mathrm{kg}$ seed) which was significantly superior over rest of the treatments. The minimum phosphorus uptake $\left(3.87 \mathrm{~kg} \mathrm{ha}^{-1}\right)$ was recorded in control. Application of RDF, $\mathrm{Zn}$ and Mo with biofertilizers contained highest amount of phosphorus as compared to the control. Similar findings were observed by Singh and Manohar (1982).

The maximum zinc uptake (654.66 $\mathrm{g} \mathrm{ha}^{-1}$ ) was recorded with the treatment of $\mathrm{T}_{8}(\mathrm{RDF}+$ $25 \mathrm{~kg} \mathrm{ZnSO}_{4} / \mathrm{ha}+$ Seed inoculation with Rhizobium $+\mathrm{PSB}+1.0 \mathrm{~g}$ Ammonium Molybdate/ kg seed) which was statistically at par with treatment $\mathrm{T}_{6}(\mathrm{RDF}+$ Seed inoculation with Rhizobium + PSB $+1.0 \mathrm{~g}$ Ammonium Molybdate/ $\mathrm{kg}$ seed) having $612.62 \mathrm{~g} \mathrm{ha}^{-1}$ zinc uptake and significantly superior over rest of the treatments. The minimum zinc uptake (406.63 $\mathrm{g} \mathrm{ha}^{-1}$ ) was recorded in control. Addition of biofertilizers, $\mathrm{ZnSO}_{4}$ and ammonium molybdatewith RDF increased zinc uptake. The increase might be due to better crop growth and development.
Similar results have been reported by Saber and Kabesh and Malewar et al., (1990).

The data on molybdenum uptake by lentil crop as influenced by various treatments have been presented in Table 2 . It clearly indicates that the maximum molybdenum uptake (278.69 $\left.\mathrm{g} \mathrm{ha}^{-1}\right)$ was recorded with the treatment $\left(\mathrm{RDF}+25 \mathrm{~kg} \mathrm{ZnSO}_{4} /\right.$ ha + Seed inoculation with Rhizobium $+\mathrm{PSB}+1.0 \mathrm{~g}$ Ammonium Molybdate/ $\mathrm{kg}$ seed) which was statistically at par with treatment (RDF + Seed inoculation with Rhizobium + PSB + $1.0 \mathrm{~g}$ Ammonium Molybdate/ $\mathrm{kg}$ seed) having $257.83 \mathrm{~g} \mathrm{ha}^{-1}$ molybdenum uptake and significantly superior over rest of the treatments. The minimum molybdenum uptake $\left(171.10 \mathrm{~g} \mathrm{ha}^{-1}\right)$ was recorded in control. Application of RDF, Zn and Mo with biofertilizers contained highest amount of molybdenum as compared to the control. Similar findings were also observed by Kumar and Sharma (2005).

\section{References}

Antoun, H. (2003). Field and Greenhouse trials performed with phosphate solubilizing bacteria and fungi. Department of soil and agrifood Engineering, Faculty of Agriculture and Food science, Laval University Québec, Canada. 4: p.67-69.

Bera, A.K., Pramanik, K. and Panda, D. (2013). Response of biofertilizers and homobrassinoloids on growth, relative water content and yield of lentil. J. Crop Weed 9: 84-90.

Gyaneshwar, P., Kumar, G.N., Paresh, L.T. and Pole, P.S. (2002) Role of soil microorganisms in improving ' $\mathrm{P}$ ' nutrients of plants. Plant and Soil, 245:83 - 93.

Hafeez, F.Y., Shah N.H. and Malik K.A. (2000). Field evaluation of lentil cultivars inoculated with Rhizobium leguminosarum bv. viciae strains for nitrogen fixation using nitrogen-15 isotope dilution. Biol Fertil Soils, 31: 65-69.

Hossain, M.A., Quddus, M.A. and Mondol, R.H. 
(2010) Requirement of zinc for LentilMungbean in calcareous and noncalcareous soil. Annual Research Report, 2009-2010. Pulse Research Centre, BARI, Gazipur.

Idries, Mohammad and Sandhu, G. R. (1979). Rhizobium inoculation in the mungbean cultivation. J. Sci., 31 (3-4): 165-173.

Jackson, M. L. (1973). Soil chemical analysis. Prentice hall of India Pvt. Ltd. New Delhi.

Jagdale, N. G., More, B. B., Kove, B. K. and Patil, P. L.L. (1980). Effect of different dose of Rhizobium inoculation on nodulation, dry matter weight, nitrogen content and yield of bangal gram. Fill. Pnn. Agric. (1) 19:216217.

Johal, R.K. and Chahal, V.P.S. (1994) Effect of Rhizobium inoculation and molybdenum on $\mathrm{N}$-fixation and growth characteristic of mungbean (Vigna radiate L.). Indian $J$. Ecol. 21(2). 160-162.

Kumar, D., Vinay-Singh, Kumar; N. and Singh, V. (1993). Interaction of $P$ and Mo for yield and uptake of $\mathrm{P}, \mathrm{Mo}$ and $\mathrm{Fe}$ in lentil. Ann. Agric. Res., 14 (4): 392-395.

Kumar, J. and Sharma, M. (2005). Effect of phosphorus and molybdenum on yield and nutrient uptake by chickpea (Cicer arietinum L.). Advances in Plant Science 18 (2): 869-873.

Kumar, J. and Sharma, M. (2005). Effect of phosphorus and molybdenum on yield and nutrient uptake by chickpea (Cecer arietinum L.). Advances in Plant Science 18 (2): 869-873.

Kumpawat, B. S. and Manohar, S. 1994. Effect of Rhizobium inoculation, phosphorus and micronutrients on nodulation and protein content of gram. Madras Agric. J. 81 (11): 630-631.
Malewar, G. U. Mangnale, M. M. and Malewar, V. (1990). Chemical composition and quality of mung genotype as influenced by zinc fertilizer. Legume Research, 13 (2): 59-64.

Mishra, S. K. and Tiwari, V. N. (2001) Effect of phosphorus, sulphur and Biofertilizer on yield, nodulation and quality of pea. Ann. Plant and Soil Research, 3(2): 2002-2005.

Possinghum (1956, 57). Plant Physiology and Biochemistry. S. Chand and Company Ltd., 118.

Saber, M.S.M. and Kabesh, M.O. (1990). A comparative study on the effect of biofertilization of sulphur application on yield and nutrient uptake by lentil plants. Egyptian Journal Soil Science., 30 (3): 415422.

Shaw. E., and Dean, L. A. (1952). Use of dithizone as an extractant to estimate the zinc content status of soil. Soil Sci., 73, 341-347.

Singh, G. and Manohar, R. S. (1982). Study on the uptake of nitrogen and phosphorus by green gram and the quality of crop as affected by phosphorus level and foliar spray of $\mathrm{H} 2 \mathrm{So} 4$ and micro nutrient. Indian J. Agric research, 16 (4): 219-222.

Singh, G. and Manohar, R. S. (1982). Study on the uptake of nitrogen and phosphorus by green gram and the quality of crop as affected by phosphorus level and foliar spray of $\mathrm{H} 2 \mathrm{So} 4$ and micro nutrient. Indian J. Agric research, 16 (4): 219-222.

Singh, S.B., Singh, O.N. and Yadav, S.S, (2007). Effect of fertility levels, PSB and vermicom post on growth yield and quality of large seeded lentil. J. Food Legumes, 20: 52-54.

\section{How to cite this article:}

Amit Kumar Tiwari, Ved Prakash, Atik Ahmad and Singh, R.P. 2018. Effect of Biofertilizers and Micronutrients on Nutrient Uptake, Growth, Yield and Yield Attributes of Lentil (Lens culinaris L.). Int.J.Curr.Microbiol.App.Sci. 7(02): 3269-3275.

doi: https://doi.org/10.20546/ijcmas.2018.702.392 